\title{
Local histories of migration and mobility
}

\author{
Colin G Pooley \\ Lancaster Environment Centre, Lancaster University c.pooley@lancaster.ac.uk
}

\begin{abstract}
This paper reviews recent developments in the study of migration and mobility, suggests likely future directions and assesses their relevance for locality-based studies. Emphasis is placed on the connections between residential migration and daily mobility and on the contribution of mobility studies to migration research. Four key themes are pursued: the development of large digitized databases, the potential use of genetic data, the importance of longitudinal studies of migration, and the value of biographical information for migration research. It is suggested that more emphasis could be placed on comparative studies both within Britain and between Britain and other countries, on the role of transport and communications in migration, and on the ways in which migration and mobility connect to the wider social, economic, cultural and political structures of society.
\end{abstract}

\section{Introduction}

The ability to move freely from one location to another is a fundamental human right. ${ }^{1}$ It is one way in which people are able to shape their lives and connect to the economic, social and cultural structures of the societies in which they live. Such moves can be over any distance or timescale, and include (for example) long-distance international migration, the movement of refugees from zones of conflict, residential change within one country, and short-distance daily travel to school, work, for ${ }^{2}$ shopping or to socialize. All such movement has a local dimension. It removes migrants from places

\footnotetext{
${ }^{1}$, United Nations Universal Declaration of Human Rights (Article 13): http://www.un.org/en/universaldeclaration-human-rights/index.html (Accessed August 2017).
} 
of origin, brings new inhabitants to places of destination, or redistributes people on a daily basis. It can divide families, disrupt local social, economic and cultural structures, and influence politics at both local and national levels. It can also be life enhancing: providing new opportunities and fresh perspectives. Although much contemporary discourse focuses attention on global issues (such as refugee migration, global environmental change, world trade or international terrorism), and research and teaching in history has increasingly foregrounded world history or global history as a core dimension, ${ }^{3}$ I argue that in the context of migration and mobility (as for many other topics) the local remains crucial. This also reflects arguments elsewhere that demonstrate the ways in which reactions against globalization have led to increased localization of social movements, economic production and political allegiances. ${ }^{4}$ In a world where global issues are increasingly dominant I argue that there is an important role for local historical studies of migration and mobility. Not only do such studies act as a valuable counterweight to accounts of globalization, but also they often connect much more directly with the lives of the people involved.

\section{Challenges and changes}

Demographic research on population movement focuses overwhelmingly on residential moves, usually placing most emphasis on those events that relocate people over some distance to another

\footnotetext{
${ }^{3}$. For a perspective from migration historians see: A. McKeown, 'Global migration 1846-1940', Journal of World History, 15 (2004), 155-189; P. Manning and T. Trimmer, Migration in world history (London, 2005); J. Lucassen, L. Lucassen and P. Manning eds., Migration history in world history: multidisciplinary approaches (Leiden, 2010).

${ }^{4}$. For instance R. Robertson, 'Glocalization: Time-space and homogeneity-heterogeneity', in M. Featherstone, S. Lash and R Robertson eds., Global modernities (London, 1995), 25-44; L. De Haan, 'Globalization, localization and sustainable livelihood', Sociologia Ruralis, 40 (2000), 339-365.
} 
community or country. Short-distance moves within a community are relatively neglected, and the daily flows of population that occur in all places are for the most part ignored. This is regrettable, as short-distance migration and daily mobility (such as travel to work, to school, to shop or to visit friends) are by far the most common events, and also have as much potential impact on people and places as do longer-distance moves. The importance of all forms of mobility, including daily interactions, is especially highlighted by contemporary mobilities researchers. The concept of the 'new mobility paradigm ${ }^{5}$ argues for the centrality of all forms of movement (physical and virtual) to the construction of social, economic and cultural life, and sees it as one of the core structures of society shaping the lives of individuals and the personality of communities. ${ }^{6} \mathrm{I}$ argue that not only does everyday mobility have the resonances developed by mobilities theories, but also that it has a direct bearing on key demographic variables. For instance, mobility is usually necessary to meet a partner thus influencing rates of nuptiality and potential fertility; all travel has associated risks and may thus affect morbidity and mortality; and the knowledge gained through daily movements or virtual mobility may contribute to the decision-making process for a residential move. I suggest that historical demographers should consider everyday mobility alongside residential migration (both short and long distance) rather than seeing them as distinct and unconnected processes. Everyday mobility is also, of course, primarily a local process.

In addition to research on all forms of movement coming from mobilities scholars, there have been a number of other key changes and challenges to historical migration research in recent years. In this paper I focus on just four of these. Here I briefly introduce these themes and consider their

\footnotetext{
${ }^{5}$. M. Sheller and J. Urry, 'The new mobilities paradigm', Environment and Planning, A 38 (2006), 207-226.

${ }^{6}$. For discussions see for instance: T. Cresswell, On the move: Mobility in the modern western world (London, 2006); J. Urry, Mobilities (Cambridge, 2007); T. Cresswell and P. Merriman, Geographies of mobilities: Practices, spaces, subjects (Farnham, 2011); P. Merriman, Mobility, space and culture (London, 2012).
} 
relevance for locality-based historical demography. In the subsequent section I suggest a possible research agenda for future studies of local populations which in part responds to some of these challenges. First, there has been an increasing emphasis on the importance of 'big data', facilitated by a combination of improved computing power and greater data availability, be that through the digitization of existing records ${ }^{7}$ or the collection of new data through means such as crowdsourcing. ${ }^{8}$ In Britain one of the most important developments in the digitization of census data that may be used for migration research has been the Integrated Census Microdata project (I-CeM). ${ }^{9}$ This provides anonymized records from (almost) all of the census enumerators' books of England, Scotland and Wales from $1851-1911,{ }^{10}$ thus allowing detailed statistical and spatial analysis of residential change from place of birth to place of residence on census night over six decades. ${ }^{11}$ While

\footnotetext{
${ }^{7}$. There are a number of large projects working with digitized data that is useful for historical demography, and which make these data widely available to researchers. These include (for example) the Minnesota Population Centre, University of Minnesota, USA (https://pop.umn.edu/) and the Demographic Data Base in Umeå, University, Sweden (http://www.cedar.umu.se/english/ddb/). For family historians commercial organizations such as Ancestry (https://www.ancestry.co.uk/) and Find My Past (http://www.findmypast.com/) provide extensive access to digitized data (All accessed August 2017).
}

${ }^{8}$. E. Estellés-Arolas and F. González-Ladrón-De-Guevara, 'Towards an integrated crowdsourcing definition', Journal of Information Science, 38 (2012), 189-200.

${ }^{9}$. For details see: http://www.essex.ac.uk/history/research/ICeM/default.htm. I-CeM data may be accessed via the UK Data Archive: http://icem.data-archive.ac.uk/(Both accessed August 2017)

${ }^{10} .1871$ data for England and Wales and 1911 data for Scotland are missing from the I-CeM data set.

\footnotetext{
${ }^{11}$. For instance the on-going research of Kevin Schurer (University of Leicester) and Joe Day (University of Cambridge).
} 
such data most obviously lend themselves to the study of large areas (the whole country or regions within Britain), the ready availability of parish-level data also provides opportunities for local studies. Unfortunately, the anonymized data do not allow the record linkage of individuals.

A second area where there have been significant advances in both scientific techniques and data availability is in the use of genetic markers to examine stability and movement within human populations. By analysing the DNA of present-day populations it is possible to identify likely migrant origins, locate regions where a distinctive gene pool has been maintained and, through the analysis of archaeological remains, to establish links to the DNA of past populations. Such techniques may be used to examine large-scale movements over long time periods, ${ }^{12}$ regional and local clustering of distinctive populations, ${ }^{13}$ or - as in the celebrated case of King Richard III - match DNA from human remains to known living relatives to prove the identity of a skeleton. ${ }^{14}$ The commercial family history

12. P. de Knijff, 'Population Genetics and the Migration of Modern Humans (Homo Sapiens)', in J. Lucassen, L. Lucassen and P. Manning eds., Migration history in world history: Multidisciplinary approaches (Leiden, 2010), 39-58; L. Cassidy, E. Rui Martiniano, M. Murphy, M. Teasdale, J. Mallory, B. Hartwell, and D. Bradley, 'Neolithic and Bronze Age migration to Ireland and establishment of the insular Atlantic genome,' Proceedings of the National Academy of Sciences, 113 (2016), 368-373.

${ }^{13}$. J. Relethford, M. Crawford and J. Blangero, 'Genetic drift and gene flow in post-famine Ireland,' Human Biology 69 (1997), 443-465; N. Rosenberg, J. Pritchard, J. Weber, H. Cann, K. Kidd, L. Zhivotovsky and M. Feldman, 'Genetic structure of human populations,' Science, 298 (2002), 2381-2385; J. Kandt, J. Cheshire, and P. Longley, 'Regional surnames and genetic structure in Great Britain,' Transactions of the Institute of British Geographers, 41 (2016), 554-569.

${ }^{14}$. T. King, G. Gonzalez Fortes, P. Balaresque, M. Thomas, D. Balding, P. Maisano Delser, R. Neumann et al., 'Identification of the remains of King Richard III,' Nature Communications, 5 (2014), 1-8. 
company Ancestry now even offers a DNA testing service to try to establish information about where an individual's ancestors may have come from and who they might be related to. ${ }^{15}$ Although such research requires the combination of a range of rather different skills, there must be potential to utilize data gained from research on human genetics to learn more about the composition and origins of local populations.

Migration research in Britain suffers from the lack of genuinely longitudinal data. This means that most migration studies rely on census birthplace data which, necessarily, provide only a partial view of life-time migration experiences. Most moves that occur between census years are missed (though some may be inferred from the birthplaces of children), leading to both the total volume of migration being misrepresented and certain categories of migration (such as frequent short-distance moves within one community) being disproportionately under-recorded. In contrast, in much of continental Europe population registration provides longitudinal data that records all residential moves and thus allows a much fuller picture of migration and population change to be established. ${ }^{16}$ One challenge for British migration historians has been to find ways to fill the gaps left by census birthplace data and to reconstruct something approaching a longitudinal dataset. Probably the most comprehensive attempt to do this so far used data collected from family historians from all parts of

${ }^{15}$. Ancestry DNA: https://www.ancestry.co.uk/dna/(Accessed August 2017).

${ }^{16}$. See for example J. Adams, A. Kasakoff and J. Kok, 'Migration over the life course in XIXth century Netherlands and the American north: a comparative analysis based on genealogies and population registers,' Annales de Démographie Historique, 2 (2002), 5-27; J. Kok, 'Choices and constraints in the migration of families: The central Netherlands, 1850-1940,' The History of the Family, 9 (2004), 137-158; L. Vikström,, 'Gendered routes and courses: the socio-spatial mobility of migrants in nineteenth-century Sundsvall, Sweden,' Demographic Data Base (DDB) Research Report 21, (Umeå, Sweden, 2003). 
the country to reconstruct life-time residential histories for over 16,000 individuals. ${ }^{17}$ These data provided good estimates of migratory change at national and regional levels but sample sizes were too small to allow analysis in specific localities. Since this study the digitization of many nominal records has made it much easier (though by no means straightforward and still very timeconsuming) to construct individual life histories, and there will still be gaps in the record as moves that occurred between recorded events will be missed. ${ }^{18}$ The detailed record linkage required to construct individual migration life histories is most easily tackled at a local level and there is scope for many more migration studies that generate genuinely longitudinal data that captures most (if not all) residential moves undertaken by a sample of individuals.

One way in which more complete data on individual mobility (both residential migration and daily movements) can be captured is through the use of life writing. This can take the form of diaries, letters, life histories and autobiographies. Although necessarily restricted to a very small (and in no way statistically representative) sample of people, an approach through life writing can provide a fresh perspective on the frequency and experiences of population movement, together with its motives and effects. A biographical approach to the study of migration is not new, ${ }^{19}$ but it has been

${ }^{17}$. C. Pooley and J. Turnbull, Migration and mobility in Britain since the eighteenth century, (London, 1998). Data from this study are available from the UK Data Archive (Longitudinal Study of Residential Histories, 17501994 (SN 3571): http://data-archive.ac.uk/(Accessed August 2017).

${ }^{18}$. One large-scale study that uses digitized census data to link individuals between 1851 and 1881 is: J. Long, 'Rural-urban migration and socioeconomic mobility in Victorian Britain,' Journal of Economic History, 65 (2005), 1-35.

${ }^{19}$. See for instance: K. Halfacree and P. Boyle, 'The challenge facing migration research: the case for a biographical approach,' Progress in Human Geography, 17 (1993), 333-348; R. Skeldon, 'The challenge facing migration research: a case for greater awareness,' Progress in Human Geography, 19 (1995), 91-96; A. Findlay, 
used relatively rarely in historical research where the researcher must rely on scarce, scattered and often hard to read diaries or accounts rather than on the more easily-collected interview data used in contemporary studies. ${ }^{20}$ Life writing sources can also be used to (at least partially) reconstruct everyday mobility: an aspect of population movement that is unlikely to be recorded in any other sources. Such studies allow the exploration in an historical context of the mobilities concepts mentioned above. ${ }^{21}$ Used in conjunction with other sources life writing ca provide significant insights into the experiences of mobility and migration at the local level.

\section{Responses: towards a research agenda}

Because sources for the detailed historical study of migration and mobility are so limited it is never likely to be possible to answer all the questions that might be raised. However, it is the case that approaches through local studies can provide insights that may be missed in research conducted at the regional or national level. In this section I suggest some avenues along which future research on migration and mobility might progress, how it might meet some of the challenges outlined above

and F. Li, 'An auto-biographical approach to understanding migration: the case of Hong Kong emigrants,' Area, 29 (1997), 34-44.

${ }^{20}$. C. Pooley and S. D'Cruze, 'Migration and urbanization in northwest England circa 1760-1830,' Social History, 19 (1994), 339-358; C. Pooley and J. Turnbull, 'Changing home and workplace in Victorian London: the life of Henry Jaques, shirtmaker,' Urban History, 24 (1997), 148-178.

${ }^{21}$. C. Pooley and M. Pooley, 'Mrs Harvey came home from Norwich... her pocket picked at the station and all her money stolen,' Journal of Migration History, 1 (2015), 54-74; C. Pooley, 'Cities, spaces and movement: everyday experiences of urban travel in England c1840-1940', Urban History, 44 (2017), 91-109; C. Pooley, 'Travelling through the city: using life writing to explore individual experiences of urban travel c1840-1940', Mobilities, 12 (2017), 598-609. 
and where the local dimension is particularly important. Of course, these are not the only avenues that may be pursued, and most are not in themselves new. However, there is considerable scope to extend and develop existing research in all these areas.

Comparative studies of migration and mobility either within one country or between different nations are relatively rare, due in part to the time-consuming nature of such research and the incompatibility of sources in different countries. At the international level in particular this has led to a tendency to emphasize the differences between countries, and to argue for a degree of exceptionalism with regard to migration in Britain. However, detailed comparative studies can challenge such assumptions and usually show that processes of migration operated in similar ways over both time and space. ${ }^{22}$ Even within Britain although there are many excellent studies of aspects of migration to and within specific localities, there are few genuinely comparative studies of regions or communities. ${ }^{23}$ It would be good to see more carefully chosen comparative studies of migration and mobility in the pages of this journal and elsewhere.

\footnotetext{
${ }^{22}$. For a fuller discussion of this theme in the context of migration in Britain and Sweden see: C. Pooley, 'The influence of locality on migration: a comparative study of Britain and Sweden in the nineteenth century,' Local Population Studies, 90 (2013), 13-27.
}

${ }^{23}$. Recent locality-based studies of various aspects of migration and mobility (or immobility) in Britain include:

L. Tabili, Global migrants, local culture: natives and newcomers in provincial England, 1841-1939 (London, 2011); C. Pooley, 'Migrants and the media in nineteenth-century Liverpool,' Local Population Studies, 92 (2014), 24-37; L. Boothman, 'Studying the stayers: the stable population of Long Melford, Suffolk, over two hundred years,' Local Population Studies, 95 (2015), 9-28; S. Taylor, 'Poverty, emigration and family: Experiencing childhood poverty in late-nineteenth century Manchester,' Family and Community History, 18 (2015), 89-103. 
There is considerable scope for historical research on migration and mobility to engage more with the ideas and concepts used by contemporary mobility researchers (outlined briefly above) and, especially, to examine the connections between residential migration and everyday mobility. As mentioned above not only is daily mobility rarely studied from an historical perspective (and this is something that can only be investigated at the local level by using detailed archival sources including life writing), but also the ways in which everyday travel might influence residential migration have been almost totally neglected. There have been some studies of the links between residential moves and travel to work distances, especially in the twentieth century as improved transport allowed longer commuting journeys and gave people a genuine choice of either moving home or a longer journey to work, ${ }^{24}$ but in other contexts the links remain largely unexplored. There has also been very little consideration of the role of transport in historical studies of migration or mobility. The availability of transport, both in terms of technological change and personal access can influence the ability of people to move over longer distances, and may affect everyday decisions about migration and mobility. Such connections, between migration, mobility and transport can most easily be investigated at the local level and could form fruitful areas of research for LPSS members. ${ }^{25}$ For

${ }^{24}$. See for instance: A. Green, T. Hogarth and R. Shackleton, 'Longer distance commuting as a substitute for migration in Britain: a review of trends, issues and implications,' International Journal of Population Geography, 5 (1999), 49; C. Pooley, 'Mobility in the twentieth century: Substituting commuting for migration?,' in D. Gilbert, D. Matless and B. Short eds., Geographies of British modernity: Space and society in the twentieth century (Oxford, 2003), 80-96.

${ }^{25}$. For a more detailed discussion of this theme see: C. Pooley, 'Mobility, Migration and Transport: Historical Perspectives,' (London, 2017); C. Pooley, 'Connecting historical studies of transport, mobility and migration', Journal of Transport History, (On-line First, June 2017:

http://journals.sagepub.com.ezproxy.lancs.ac.uk/doi/full/10.1177/0022526617715538). 
instance, how did changes in public transport provision and shifts in access to private modes of travel in the twentieth century influence the propensity to travel, widen horizons and thus potentially influence a future residential move?

All forms of movement are experiences that have the potential to stick in the mind and to influence later decisions about travel for any reason. However, in an historical context the experience of travel - be it for residential migration or for everyday mobility - is hard to study. While contemporary researchers may interview respondents the historical researcher relies on archival records or oral history. Both present problems as experiences are rarely recorded in official records and memories of mundane everyday events such as travel may fade or be distorted by later experiences. Most studies of migration rely on census or registration records which can provide information on the size, composition and direction of movement, but almost nothing on the experience of a move. Local historical studies are well placed to fill this gap and to not only focus on the bare statistics of movement but to also explore the experiences of such travel and the possible impacts of movement on later mobility decisions and associated life events. ${ }^{26}$ Relevant information may be gained from a range of archival and family history sources including local newspapers, personal accounts, letters, diaries and life histories. The time-consuming nature of such research means that it must be conducted at the local level, but if more such studies were available then some generalization may also be possible. I urge historical demographers working at the local level to consider not only the statistics of movement but also the personal benefits, costs and experiences of these potentially lifechanging events.

Population movement is not disconnected from the society and culture in which it is situated, but all too often when viewed through the largely statistical lens of the historical demographer this does

\footnotetext{
${ }^{26}$. See C. Pooley, 'How people moved: researching the experience of mobility in the past,' Local Population Studies, 82 (2009), 63-70.
} 
seem to be the case. Through studies at the local level it is possible to examine such connections much more closely and to consider the ways in which migration and mobility affect not only the individuals involved but also the societies and communities in which it is located and which are affected by such movement. While some forms of mobility may take place almost unnoticed, most will have an impact on both communities of loss and gain. Such impacts may be economic, social, cultural or environmental, but above all they all have potential political implications that may, in turn, shape future society. We know that attitudes to migrants in twenty-first century Britain have shaped political views, contributing to increased prejudice against some groups of the population and the vote in June 2016 to leave the European Union in an attempt to more directly control migration from the EU (among other issues). However, the ways in which population movement influenced social attitudes and political persuasions in the past is much more rarely studied. There is, of course, much well-documented evidence for both local and national prejudice against large and high-profile groups of migrants such as Catholic Irish in the mid-nineteenth century and Jewish migrants from Eastern Europe in the late-nineteenth and early-twentieth centuries, ${ }^{27}$ but attitudes towards other less visible migrants are harder to discern and more rarely considered. ${ }^{28}$ However, the impact of all forms of population movement on individual communities can be considerable, and the ways in which it shaped social attitudes and local politics can only be studied through the use of detailed local archival sources. As with all the above themes, if such studies can also be conducted

27. See for example: R. Swift and S. Gilley, The Irish in Britain, 1815-1939 (Savage, MD, 1989); D. MacRaild, Culture, conflict, and migration: the Irish in Victorian Cumbria (Liverpool, 1998); J. Belchem, Irish, Catholic and Scouse: The History of the Liverpool-Irish, 1800-1939 (Oxford, 2007); B. Williams, The Making of Manchester Jewry, 1740-1875 (Manchester, 1985; D. Cesarani, 'An Embattled Minority: The Jews in Britain during the First World War,' Immigrants and Minorities, 8 (1989), 60-81; V. Lipman, A History of the Jews in Britain since 1858 (Leicester, 1990).

${ }^{28}$. See Pooley, 'Migrants and the media. 
within a longitudinal frame, looking at changes over time and shifts in attitudes, experiences and expectations this is an added bonus to research in local population history.

\section{Conclusions}

Migration and mobility are in many ways the neglected dimensions of historical demography. Unlike fertility and mortality population movement is not a finite event that can be easily recorded or measured. Movement takes place over any distance, many times in the lives of most people, and with a wide range of potential effects. This was recognized ten years ago by Richard Smith who stated that migration 'has been treated as a shadowy variable' by historical demographers. ${ }^{29}$ Little has changed since then with only around 14 per cent of substantive contributions to LPS in the last 20 issues devoted to any aspect of migration, mobility or ethnicity. This short article has argued not only that migration and mobility are important (and connected) aspects of population change, but also that they have especial resonance at the local level. I also argue that there remain many important and exciting avenues for future research within which local studies can make a critical contribution. Indeed, many topics can only be effectively studied at the local level. The itinerary of current challenges and future research avenues that I present is not, of course, exhaustive: many other themes could be identified. However, hopefully this article will stimulate more readers of this journal to turn their attention to the study of migration and mobility in their locality, and to think critically and incisively about the role of all forms of movement in historical demography.

\footnotetext{
${ }^{29}$. R. Smith, 'Linking the local and the general in population history: prioritising migration', Local Population Studies, 81 (2008), 9-10.
} 


\section{Author autobiographical note:}

Colin G Pooley is Emeritus Professor of Social and Historical Geography in the Environment Centre, Lancaster University, UK. He has published widely on the history of migration, mobility and transport in Britain. 